(c) American Dairy Science Association, 2005.

\title{
Partial Identification of Water-Soluble Peptides Released at Early Stages of Proteolysis in Sterilized Ovine Cheese-Like Systems: Influence of Type of Coagulant and Starter
}

\author{
S. V. Silva and F. X. Malcata \\ Escola Superior de Biotecnologia, P-4200-072 Porto, Portugal
}

\begin{abstract}
Cheese-like systems were manufactured from sterilized ovine milk, using crude aqueous extracts of $C y$ nara cardunculus or cardosin A isolated therefrom as clotting agent. The effect of adding a commercial starter culture was also assessed. The impact of the type of coagulant used during the initial $24 \mathrm{~h}$ of proteolysis was evaluated via separation of peptides in the watersoluble extracts by reverse-phase HPLC, followed by partial sequencing via Edman degradation. Cardosin A accounted for most events of primary proteolysis. The major cleavage sites were Phe105-Met106 in $\kappa$-casein, and Leu127-Thr128, Ser142-Trp143, Leu165-Ser166, and Leu190-Tyr191 in $\beta$-casein. The starter culture did not play an active role during the initial stages of ripening.
\end{abstract}

(Key words: casein hydrolysis, Cynara cardunculus, rennet, RP-HPLC)

Abbreviation key: RP-HPLC = reverse-phase highperformance liquid chromatography, WISE = waterinsoluble extract, $\mathbf{W S E}$ = water-soluble extract.

\section{INTRODUCTION}

Rennet substitutes of plant origin are not often used in cheese making. However, the proteinases present in the flowers of Cynara cardunculus, viz. cardosins A and $\mathrm{B}$, have been successfully employed for centuries in the Iberian Peninsula for cheese making at the farm level (Vieira de Sá and Barbosa, 1972; Pires et al., 1994; Trujillo et al., 1994). Cardosin A is similar, in terms of specificity and activity, to chymosin, whereas cardosin B resembles pepsin (Veríssimo et al., 1995). The use of this plant rennet often entails problems regarding curd formation and final cheese characteristics, probably because the coagulant activities are difficult to standardize.

Received October 7, 2004.

Accepted February 1, 2005.

Corresponding author: F. X. Malcata; e-mail: fxmalcata@esb. ucp.pt.
Whereas most of the rennet added to milk during cheese making is eventually lost in whey, a minor fraction that depends on the type of cheese (Choisy et al., 2000 ) is retained within the curd; this fraction is responsible for its initial proteolysis. During this early stage, caseins are hydrolyzed into large, well-defined peptides via residual rennet, which are subsequently digested into smaller ones and even free AA by enzymes contributed by starter or nonstarter microorganisms (Benfeldt and Sørensen, 2001). Primary proteolysis is possibly the most important set of events toward the development of flavor and texture in ripened cheeses (Fox et al., 1999).

The initial $24 \mathrm{~h}$ following coagulation are particularly important in terms of peptide release (Picon et al., 1995). Casein aggregation and whey expression continue to take place throughout that period, and afterwards, casein is compacted within the curd and water is concomitantly lost, while fat globules are entrapped and compressed (all of which determine final cheese structure and composition) (Green and Grandison, 1999).

Proteinase activities are often assessed using skim milk or solutions of casein (Hill and Gasson, 1986; Khalid et al., 1991), whereas peptidase activities usually are studied with chromogenic substrates or sodium caseinate in solution (Hickey et al., 1983; Peterson et al., 1990). However, extrapolation of results from the aforementioned liquid media to an actual solid cheese system is risky, owing to differences between their nature. Furthermore, there are studies (McSweeney et al., 1993) indicating that some of the enzyme-mediated events that occur rapidly in solution fail to do so in cheese. On the other hand, true cheese matrices are too complex and heterogeneous in nature to permit fundamental validation of the performance of proteases as they relate to proteolysis. Hence, a compromise is urged, as provided by cheese-like systems.

Considerable effort has been expended recently to characterize the process of proteolysis affected by enzymes from $C$. cardunculus during the ripening of raw ovine milk cheeses, as well as during hydrolysis of caseins in solution (Silva and Malcata, 1998, 2004, 2005; Sousa and Malcata, 1998a,b; Silva, 1999; Silva et al., 
2002). However, very little data are available in the literature regarding the use of sterilized milk as substrate, and information is even scarcer regarding the initial $24 \mathrm{~h}$ of ripening, especially when a coagulant of plant origin is concerned (Silva and Malcata, 2004). On the other hand, the effect of the presence (or absence) of a starter culture is important because it typically is present in relatively higher numbers during the early stages of ripening, either adventitiously in milk or deliberately added during cheese making, and it possesses significant activity that may contribute to proteolysis.

Overall bulk characterization of nitrogen in watersoluble extracts of cheese is a commonly used index of cheese ripening (Fox et al., 1999); reverse-phase HPLC (RP-HPLC) has proven suitable to resolve and analyze the peptides and AA therein, which sets the basis for a more refined and meaningful characterization.

Therefore, the aim of this work was to isolate the peptides (and identify the cleavage sites within their percursor caseins) in the water-soluble fraction of cheese-like systems, manufactured with crude aqueous extracts of C. cardunculus or isolated cardosin A during the initial stages of ripening, in the presence or absence of starter culture, in an attempt to gain a deeper understanding of the unique features of said coagulant.

\section{MATERIALS AND METHODS}

\section{Cheese Making and Sampling}

Milk produced by selected ewes of the Bordaleira breed was heated to $110^{\circ} \mathrm{C}$ for $10 \mathrm{~min}$. Milk sterility was defined as the absence of microorganisms on plate count agar incubated at $30^{\circ} \mathrm{C}$ for $48 \mathrm{~h}$ (Tavaria and Malcata, 1998). Milk aliquots (100 mL) were placed in $250-\mathrm{mL}$ sterilized flasks. One half of the milk aliquots were treated with commercial starter Flora danica DRI/ vac (Chr. Hansen's Lab, Denmark A/S, Copenhagen, Denmark), at the recommended level. Both types of aliquots were heated to $28^{\circ} \mathrm{C} ; 0.250 \mathrm{~mL}$ of aqueous thistle extract (or solution of cardosin A) was added under sterile conditions and left to coagulate for $45 \mathrm{~min}$. The curd was then cut, stirred, and allowed to set so as to permit draining (under sterile conditions). The whey produced was removed (again under sterile conditions) by opening the flasks every $15 \mathrm{~min}$ for $1.5 \mathrm{~h}$. The flasks were placed in a chamber maintained at $10^{\circ} \mathrm{C}$. Two cheese-like systems manufactured with each type of coagulant were randomly selected for analysis by 2,8 , and $24 \mathrm{~h}$. The average of every set of replicated analytical determinations for each set of 2 cheeses was considered as a datum point.

\section{pH Measurement}

The $\mathrm{pH}$ was measured by directly probing the curd with a glass electrode connected to a potentiometer (MicropH 2002, Crison Instruments, Barcelona, Spain).

\section{Microbiological Enumeration}

The numbers of total viable microorganisms (on plate count agar) and lactic acid bacteria (on M17 agar) in the cheese-like systems were determined according to Sousa and Malcata (1996).

\section{Extract Characterization}

The water-soluble extract (WSE) and the water-insoluble extract (WISE) were obtained by the procedure of Kuchroo and Fox (1982); the cheese-like system was homogenized in a stomacher at $20^{\circ} \mathrm{C}$ for $10 \mathrm{~min}$ with twice its weight of water; the slurry was then held at $40^{\circ} \mathrm{C}$ for $1 \mathrm{~h}$, centrifuged, and filtered. The filtrate (WSE) and the retentate (WISE) were finally freezedried. Before analysis, samples $(10 \mathrm{mg} / \mathrm{mL})$ were dissolved in $0.1 \%$ ( $\mathrm{vol} / \mathrm{vol}$ ) trifluoroacetic acid solution, and filtered through a $0.45-\mu \mathrm{m}$ cellulose acetate filter.

\section{Peptide Resolution}

Reverse-phase HPLC of WSE was performed in a Waters Alliance 2690 HPLC system, using Millenium software (Waters, Milford, MA) for system control and data acquisition. A Purospher STAR RP-18e $(5 \mu \mathrm{m})$ column (Merck, Darmstadt, Germany) was used, along with a Lichrocart 250-4 guard-column (Merck). Elution was at $40^{\circ} \mathrm{C}$ via a mobile phase of 2 solvents: A was $0.1 \%$ ( $\mathrm{vol} / \mathrm{vol}$ ) trifluoroacetic acid in water, and B was $0.1 \%(\mathrm{vol} / \mathrm{vol})$ trifluoroacetic acid in acetonitrile:water (60:40); the flow rate was $1.0 \mathrm{~mL} / \mathrm{min}$; the solvent profile started with $100 \%$ A for $10 \mathrm{~min}$, with a linear gradient from 0 to $80 \%$ B over $80 \mathrm{~min}$, and a mixture of $20 \% \mathrm{~A}$ and $80 \%$ B for 10 min (González de Llano et al., 1995); detection was by spectrophotometry at $214 \mathrm{~nm}$. Results were expressed as absorbance units.

\section{Peptide Identification}

Peptides isolated by RP-HPLC (as described above) were sequenced using an automated, pulsed liquidphase protein-peptide sequencer (model 491, Applied Biosystems, Foster City, CA). Amino acids liberated were detected as their phenylthiohydantoin derivatives. The partial sequence thus obtained was checked against the (known) sequence of caseins, so as to determine the most likely cleavage site. 


\section{Statistical Analysis}

Multivariate analysis of the peptide peak areas associated with WSE of the 4 different cheese-like systems was performed with SPSS software, v. 12.0 (SPSS Inc., Chicago, IL). Tukey's and post hoc tests were used as appropriate.

\section{RESULTS AND DISCUSSION}

The most representative portions of the RP-HPLC chromatograms of the WSE of the cheese-like systems are shown in Figure 1. Changes with ripening time in the relative peak area of the major water-soluble peptides are represented in Figure 2. Each peak represents at least one peptide, and the area of the peak is, in principle, proportional to the concentration of the peptide(s) at stake.

Inspection of Figure 1 indicates that there are few qualitative differences between the WSE of the 4 types of cheese-like systems studied. In all cases, it is apparent that most peptides were eluted between 55 and 80 min. During the initial stages of ripening, proteolysis is due mainly to the action of deliberately added coagulating enzymes retained in the curd or indigenous milk enzymes (mainly plasmin); caseins are hydrolyzed to large- to medium-sized peptides, which may be further degraded to smaller peptides. This explains why the first portion of the chromatograms is essentially void, as that portion is normally accounted for by small (hence hydrophilic) peptides (Kaiser et al., 1992; Belitz and Kaiser, 1993).

The peptide profiles of the WSE of all cheese-like systems were essentially identical. The peptides were sequenced from their $\mathrm{N}$-termini in order to identify them; these sequences are depicted in Table 1. In all cases, ovine $\kappa$-casein was cleaved by the coagulant enzyme(s) at Phe105-Met106 (peptide peak denoted as 3 in Figure 1). It was reported elsewhere (Sousa and Malcata, 1998b; Silva, 1999) that, in solution, $\kappa$-casein is hydrolyzed by enzymatic extracts from flowers of $C$. cardunculus, as well as by cardosin A isolated at the same peptide bond; in bovine $\kappa$-casein, Phe105-Met106 also is the most susceptible peptide bond. It is well established that such a peptide bond is the primary responsible for coagulation of the casein micelles during cheese making (Fox, 1999). Sousa and Malcata (1998a) have further demonstrated that such a peptide bond in $\kappa$-casein is the most labile to cleavage, not only in raw, but also in pasteurized ovine milk cheeses made with crude aqueous extracts of $C$. cardunculus (with or without added starters).

In addition to the aforementioned peak 3 , when a crude aqueous extract of $C$. cardunculus is used as the coagulant, the primary peptide peaks apparent by as soon as within $2 \mathrm{~h}$ of ripening are those denoted as 1 , $2,12,13,15,16$, and 17 . When no starter culture was used, peptide 14 became surprisingly also visible by that time. The peptide peaks that account for the highest peak areas were those denoted as $3[\kappa-(\mathrm{f} 106-*)], 13$ $[\beta$-(f191-*)] and 16 [ $\beta$-(f1-*)]; even though these areas were lower when no starter culture was employed (Figures $2 \mathrm{~A}$ and $\mathrm{B})$, differences were not significant $(P>$ 0.05 ) between the various kinds of cheese-like systems (Table 2). After $24 \mathrm{~h}$ of maturation, peptide peaks denoted as $1,2,3,7,12,13,14,15,16$, and 17 were present, irrespective of the presence of starter culture; peptide peaks $3,13,16$, and 17 [ $\beta$-(f128-*)] were those showing the highest peak areas, but significant differences between the various kinds of cheese-like systems were found only in the case of peptide 17 [ $\beta$-(f128-*)] (Table 2).

Some of the products of proteolysis of $\beta$-casein, detected by $2 \mathrm{~h}$ in WSE of cheese-like systems manufactured with extracts of $C$. cardunculus, were also detected by the same time of hydrolysis when $\beta$-casein was tested in solution (Sousa and Malcata, 1998b), namely $\beta$-(f191-*) and $\beta$-(f128-*).

The peptide profiles produced via the action of cardosin A (with or without added starter culture) were similar, except in that peptide peak denoted as 18 was only present by $8 \mathrm{~h}$ of ripening in cheeses with starter addition (Figures $1 \mathrm{C}$ and $\mathrm{D}$ ). In both cases, the primary peptides denoted as $1,2,3,4,5,6,7,12,13,14,15,16$, and 17 appeared as early as by $2 \mathrm{~h}$ of ripening. The peptides denoted as $3[\kappa$-(f106-*)], 13 [ $\beta$-(f191-*)], and 16 [ $\beta$-(f1-*)] entertained the highest peak areas; however, the presence or absence of starter culture had no significant effect on their areas. Besides peptides denoted as 3,13 , and 16 , peptides 17 [ $\beta$-(f128-*)] and 18 [ $\beta$-(f128-*)] exhibited the highest peak areas by 24 $\mathrm{h}$ of ripening (Figures $2 \mathrm{C}$ and $\mathrm{D}$ ). By this time, however, significant differences were found between cheese-like systems manufactured in the presence or in the absence of starter culture (Table 2), except for peptide 13.

When a crude aqueous extract of $C$. cardunculus is used as coagulant together with a starter culture, four additional peptide peaks are visible: 8 [ $\beta$-(f128-*)], 9 $\left[\beta\right.$-(f191-*)], $10\left[\beta-\left(\mathrm{f} 191-^{*}\right)\right]$, and $11\left[\beta-\left(\mathrm{f} 192-^{*}\right)\right]$. These peaks are not present in any of the other three situations.

Most products of proteolysis of isolated $\beta$-casein in solution, or of sodium-caseinate, by aqueous extracts of C. cardunculus (or cardosin A isolated therefrom) were detected in the WSE of sterilized ovine cheese-like systems manufactured with or without starter, using again aqueous extracts of C. cardunculus (Sousa and Malcata, 1998b; Silva, 1999); this indicates that extensive degradation of such a casein actually occurs in those cheeses. 
A
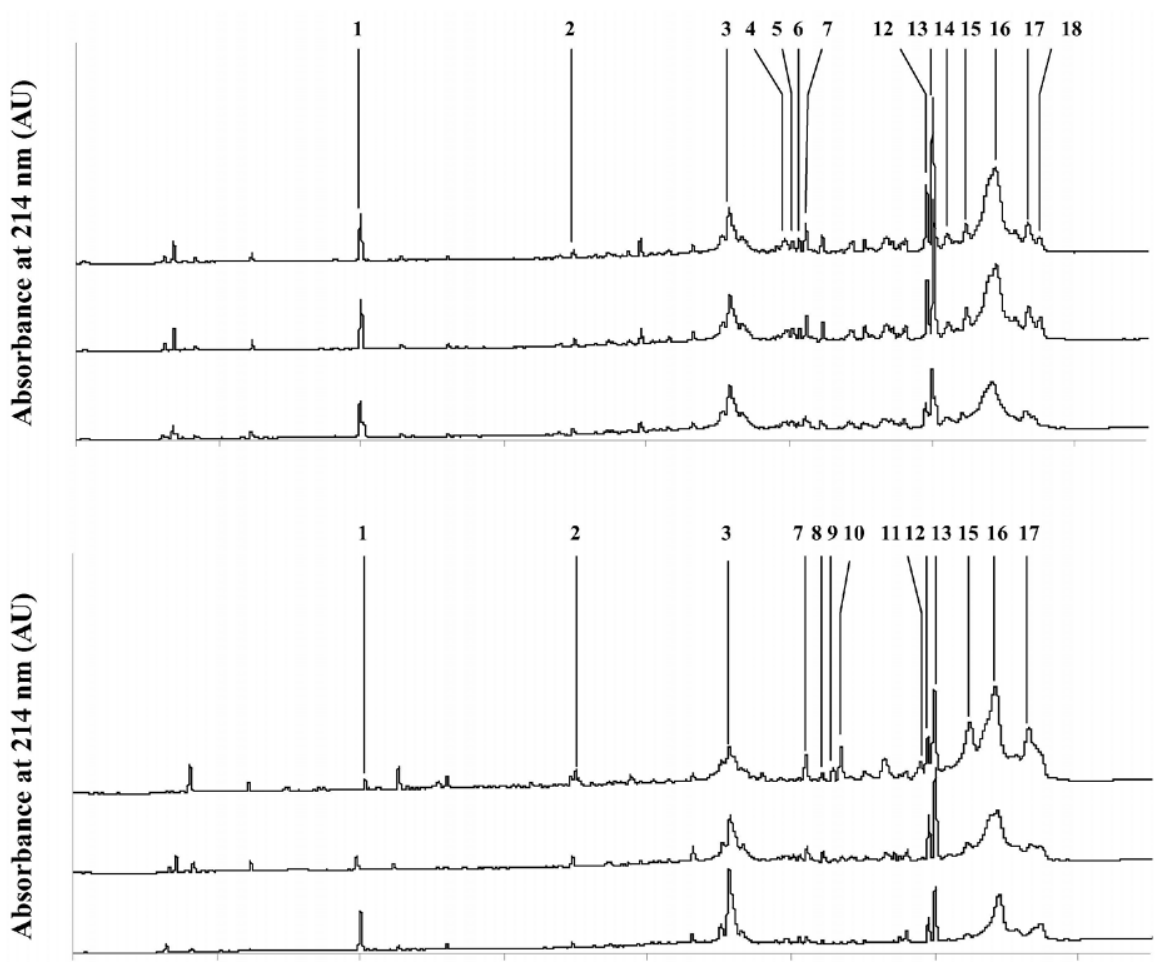

C

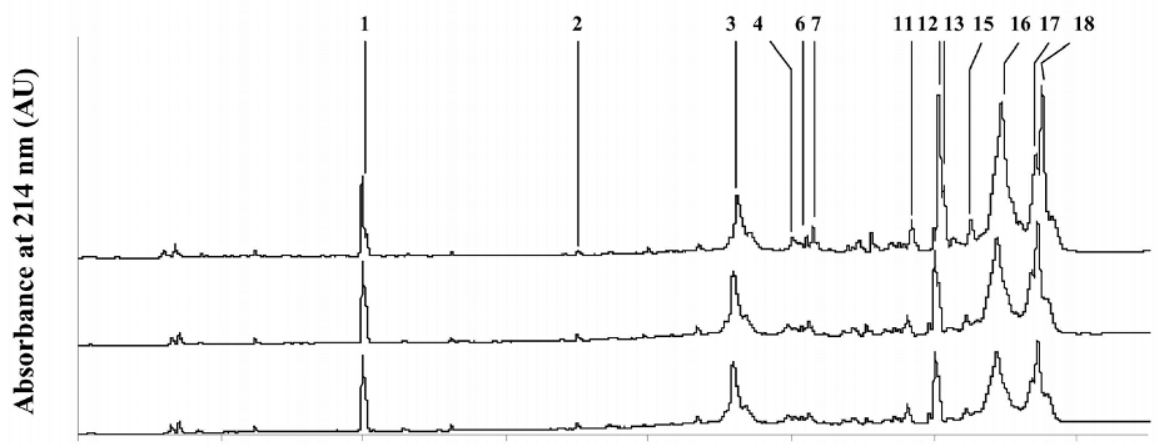

D

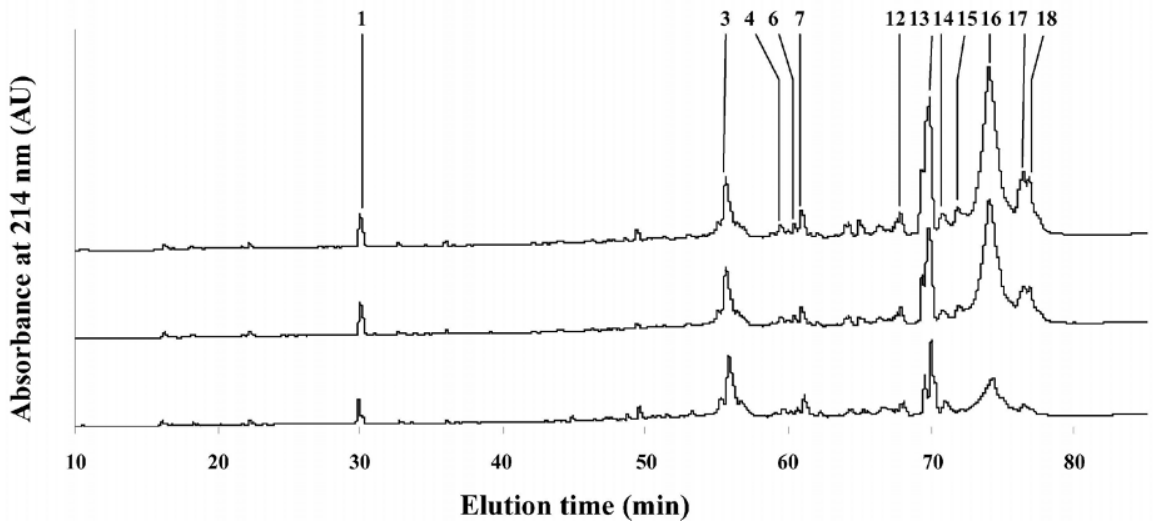

Figure 1. Reverse-phase HPLC qualitative profiles (peak locations) of the water-soluble extract of ovine cheese-like systems produced with crude aqueous extracts of Cynara cardunculus (A and B) and cardosin A (C and D), with (B and D) and without (A and C) added starters, at three different ripening times. 
A

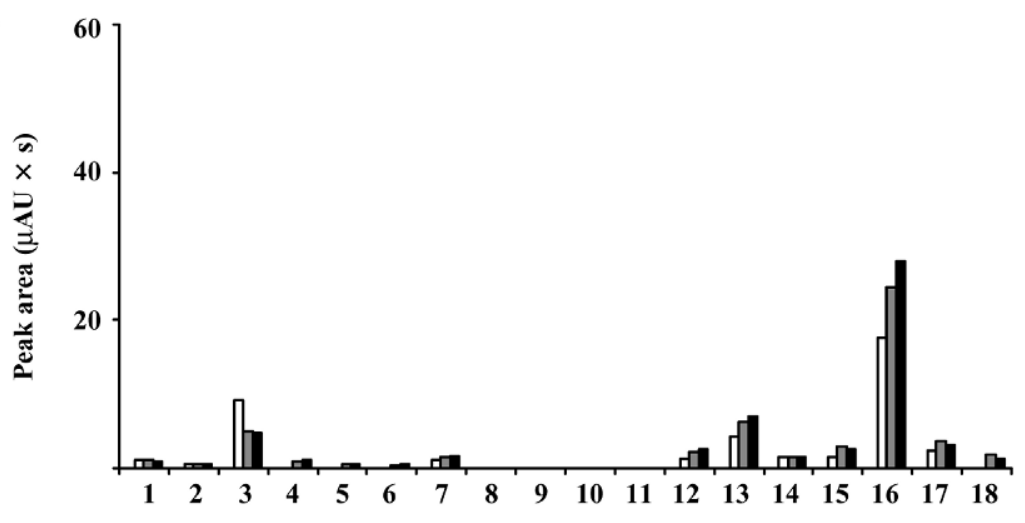

B

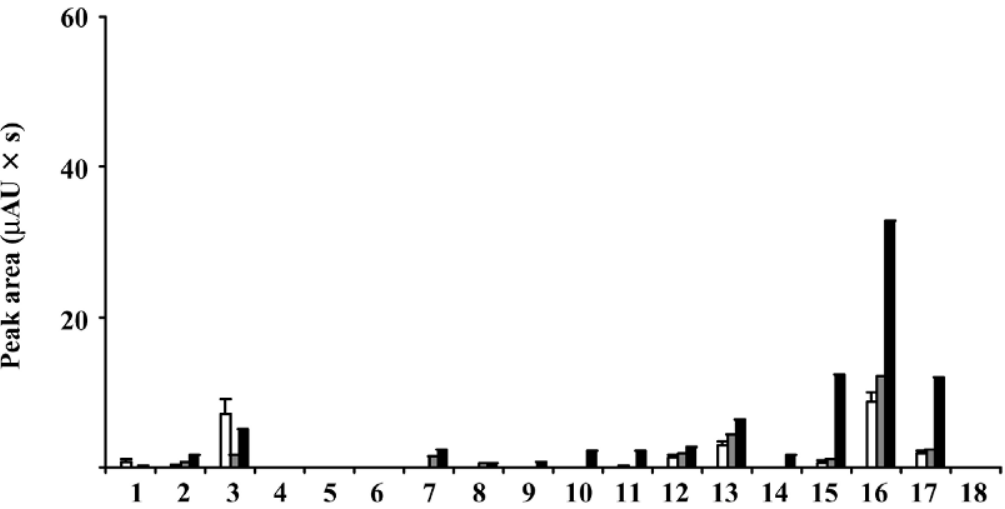

C

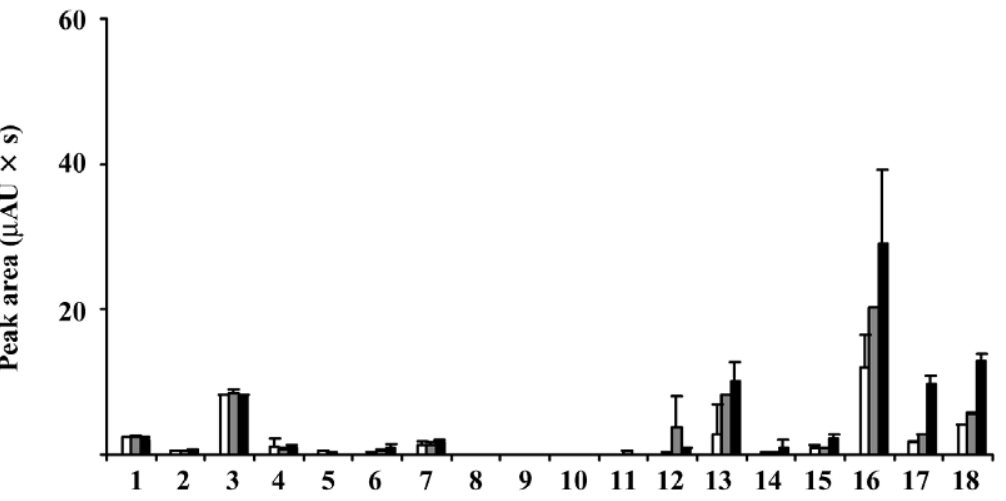

D

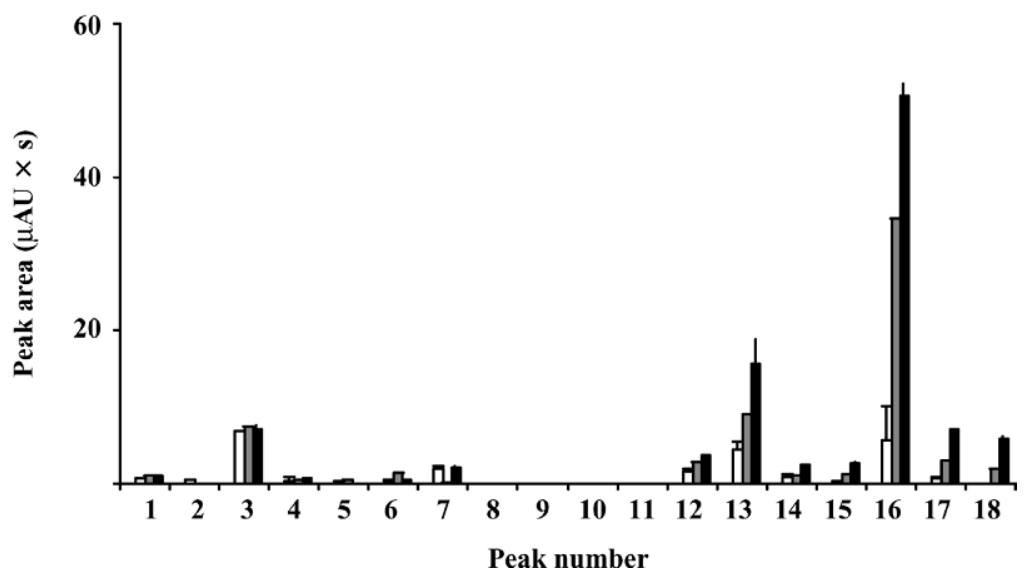

Figure 2. Reverse-phase HPLC quantitative profiles (peak areas with SD) of the water-soluble extract of ovine cheese-like systems produced with crude aqueous extracts of Cynara cardunculus (A and B) and cardosin A (C and D), with (B and D) and without (A and C) added starters, at 3 ripening times (white box, $2 \mathrm{~h}$; gray box, $8 \mathrm{~h}$; black box, $24 \mathrm{~h}$ ). 
Table 1. Identification of the major peptides present in the water-soluble fraction of ovine cheese-like systems ripened for $24 \mathrm{~h}$.

\begin{tabular}{|c|c|c|}
\hline $\begin{array}{l}\text { HPLC } \\
\text { peak no. }{ }^{1}\end{array}$ & N-terminal sequence ${ }^{2}$ & Cleavage site \\
\hline 1 & ND & - \\
\hline 2 & $\mathrm{H}_{2} \mathrm{~N}$-Ser-Gln-Pro-Lys-Val-Leu-? & Leu165-Ser166 ( $\beta$-CN) \\
\hline 3 & $\mathrm{H}_{2} \mathrm{~N}$-Met-Ala-Ile-Pro-Pro-Lys-? & Phe105-Met106 $(\kappa-\mathrm{CN})$ \\
\hline 4 & ND & - \\
\hline 5 & ND & - \\
\hline 6 & $\mathrm{H}_{2} \mathrm{~N}-\mathrm{Thr}-\mathrm{Asp}-$ Val-Glu-Lys-Leu-His-Leu-? & Leu127-Thr128 ( $\beta$-CN) \\
\hline 7 & $\mathrm{H}_{2} \mathrm{~N}$-Thr-Asp-Val-Glu-Lys-Leu-His-Leu-? & Leu127-Thr128 ( $\beta$-CN) \\
\hline 8 & $\mathrm{H}_{2} \mathrm{~N}-\mathrm{Thr}-\mathrm{Asp}-\mathrm{Val}-\mathrm{Glu}-L y s-L e u-H i s-L e u-?$ & Leu127-Thr128 ( $\beta$-CN) \\
\hline 9 & $\mathrm{H}_{2} \mathrm{~N}$-Tyr-Gln-Glu-Pro-Val-Leu-Gly-Pro-? & Leu190-Tyr191 ( $\beta$-CN) \\
\hline 10 & $\mathrm{H}_{2} \mathrm{~N}$-Tyr-Gln-Glu-Pro-Val-Leu-Gly-Pro-? & Leu190-Tyr191 ( $\beta$-CN) \\
\hline 11 & $\mathrm{H}_{2} \mathrm{~N}$-Gln-Glu-Pro-Val-Leu-Gly-Pro-? & Tyr191-Gln192 ( $\beta$-CN) \\
\hline 12 & $\mathrm{H}_{2} \mathrm{~N}$-Tyr-Gln-Glu-Pro-Val-Leu-Gly-Pro-? & Leu190-Tyr191 ( $\beta$-CN) \\
\hline 13 & $\mathrm{H}_{2} \mathrm{~N}$-Tyr-Gln-Glu-Pro-Val-Leu-Gly-Pro-? & Leu190-Tyr191 ( $\beta$-CN) \\
\hline 14 & $\mathrm{H}_{2} \mathrm{~N}$-Trp-Met-His-Gln-Pro-Pro-? & Ser142-Trp143 ( $\beta$-CN) \\
\hline 15 & $\mathrm{H}_{2} \mathrm{~N}-\mathrm{Thr}-\mathrm{Asp}-\mathrm{Val}-\mathrm{Glu}-\mathrm{Lys}-\mathrm{Leu}-\mathrm{His}-\mathrm{Leu}-?$ & Leu127-Thr128 ( $\beta$-CN) \\
\hline 16 & $\mathrm{H}_{2} \mathrm{~N}$-Arg-Glu-Gln-Glu-Glu-Leu-Asn-Val-? & - \\
\hline 17 & $\mathrm{H}_{2} \mathrm{~N}-\mathrm{Th}$-Asp-Val-Glu-Lys-Leu-His-Leu-? & Leu127-Thr128 ( $\beta$-CN) \\
\hline 18 & $\mathrm{H}_{2} \mathrm{~N}$-Thr-Asp-Val-Glu-Lys-Leu-His-Leu-? & Leu127-Thr128 ( $\beta$-CN) \\
\hline
\end{tabular}

Experimental hydrolysis of $\beta$-casein in solution by enzymes present in crude aqueous extracts of $C$. cardunculus indicated that the most susceptible peptide bonds are Leu127-Thr128 and Leu190-Tyr191 (Sousa and Malcata, 1998b). Besides these, another 2 cleavage sites were found to exist in cheese-like systems, viz. Ser142-Trp143 and Leu165-Ser166. Moreover, when a starter culture was added, the peptide bond Tyr191Gln192 was also cleaved (Table 1).

The specificity of cardosin A in cheese-like systems (made with or without starter) was similar to that ob- served in solution, insofar as the same peptide bonds in the C-terminal part of $\beta$-casein are cleaved (Silva, 1999). However, additional cleavage sites were observed, namely the peptide bond Ser142-Trp143 (Table 1).

In the case of $\alpha_{\mathrm{s} 1}$-casein, none of its highly susceptible peptide bonds when in solution was cleaved, by cardosin A or B in the crude aqueous extracts of $C$. cardunculus (or by purified cardosin A), in cheese-like systems during the initial $24 \mathrm{~h}$ of ripening. Recall that ovine $\alpha_{\mathrm{s} 1}$-casein in solution or in sodium caseinate is hy-

Table 2. Average value of peak areas, in absorbance units $\times$ elution time $(\mu \mathrm{AU} \times \mathrm{s})$, of the major peaks from the water-soluble extract of ovine cheese-like systems.

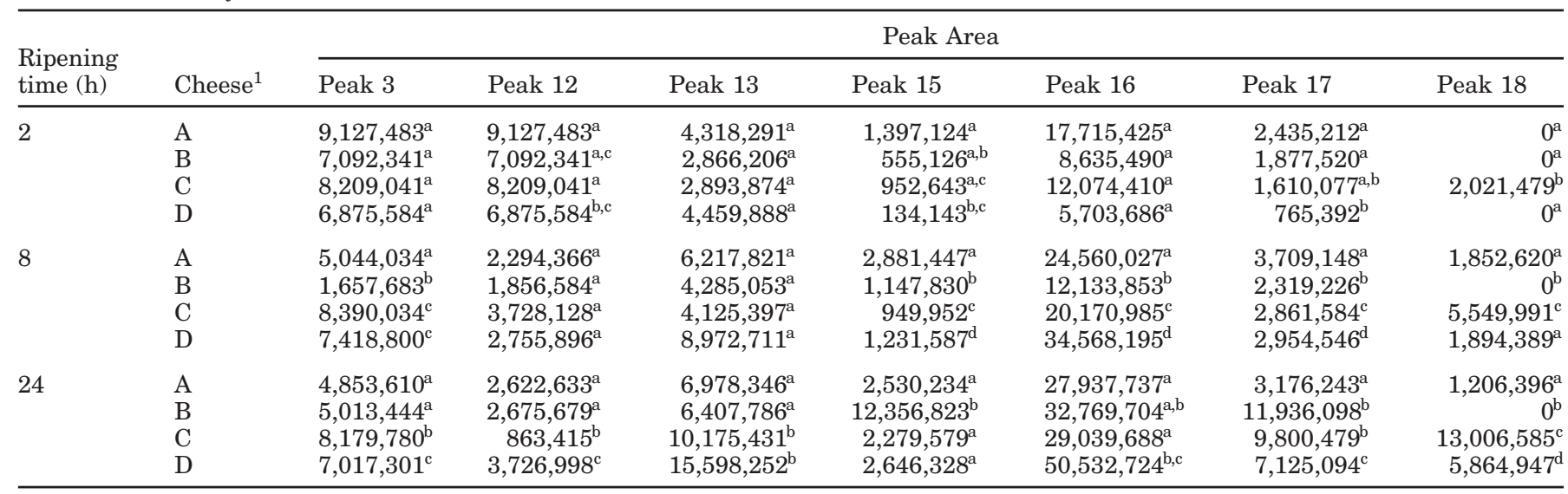

a,b,c,d Means followed by the same superscript are not statistically different from each other $(P<0.05)$.

${ }^{1} \mathrm{~A}=$ Ovine cheese-like systems, produced with crude aqueous extracts of Cynara cardunculus without added starter; $\mathrm{B}=$ ovine cheeselike systems, produced with crude aqueous extracts of $C$. cardunculus with added starter; $\mathrm{C}=$ ovine cheese-like systems, produced with cardosin A without added starter; D = ovine cheese-like systems, produced with cardosin A with added starter. 
drolyzed at peptide bonds Trp164-Tyr165 and Phe153Tyr154, respectively, by cardosin A (Silva, 1999); however, its major cleavage site in ovine caseinate by aqueous extract of $C$. cardunculus is Phe23-Val24 (Sousa and Malcata, 1998b). The cheese environment possesses a restricted water content (measured by water activity, $a_{\mathrm{w}}$ below unity) that influences the availability of water molecules to contribute to the conformation of enzyme and/or of substrate; this might help explain the differences between enzyme activity in solution and in cheese-like systems. Hence, a specific rearrangement of the $\alpha_{\mathrm{s} 1}$-casein molecule induced by a typical cheese environment may have caused the loss of lability of said peptide bonds. Moreover, the milk used in this study was sterilized ovine milk; it is known that thermal treatment of cheese milk does not directly affect the coagulating enzymes, but rather the accessibility of their substrates due to covalent attachment of whey proteins (particularly $\beta$-lactoglobulin) to the surface of the casein micelles via thiol-disulfide interchange with $\kappa$-casein (Benfeldt and Sørensen, 2001).

Statistical analysis of the peptide areas of major peaks, namely peptides denoted as 3,12 [ $\beta$-(f191-*)], 13,15 [ $\beta$-(f128-*)], 16, 17, and 18, permitted knowledge of the influence of the cheese-like system on each individual peptide throughout ripening (Table 2). After 24 $\mathrm{h}$, significant differences were found for peptide 3 between cheeses manufactured with cardosin A, irrespective of starter addition. This is understandable since cardosin A is the main enzyme responsible for the specific cleavage of the Phe105-Met106 peptide bond, whereas cardosin B is much less specific in its proteolytic action.

Concerning peptide 12 [ $\beta$-(f191-*)], significant differences were found only between the cheese-like systems manufactured with cardosin A after $2 \mathrm{~h}$ of maturation, whereas no significant differences were found between cheese-like systems manufactured with extracts of $C$. cardunculus by $24 \mathrm{~h}$.

For peptide 13, no significant differences between the various kinds of cheese-like systems were found $(P>$ 0.05 ) by $2 \mathrm{~h}$ of ripening; however, significant differences were found between cheese-like systems manufactured with cardosin A with added starter vs. no starter added $(P<0.05)$, which suggests that cardosin A is likely responsible for the appearance of this peptide.

With respect to peptide 15 , the extracts of $C$. cardunculus coupled with starter contributed significantly $(P$ $<0.05$ ) to the peptide's formation by $24 \mathrm{~h}$ of maturation, whereas a significant effect was found for peptide 16 in cheese-like systems manufactured with extracts of C. cardunculus (or with cardosin A).

Significant differences were found between cheeselike systems, except for cheeses manufactured with ex- tracts of C. cardunculus (or with cardosin A) with starter and cardosin A without starter, regarding peptide 17 by $24 \mathrm{~h}$ of ripening.

In the case of peptide 18, significant differences were found between all kinds of cheese-like systems.

The pathways of degradation of $\alpha_{\mathrm{s} 1}$ - and $\beta$-caseins by enzymes from $C$. cardunculus, as derived from solution experiments, do not necessarily mimic those in cheese; hence, straightforward extrapolation of conclusions obtained regarding caseins in solution to cheese systems is risky (Exterkate et al., 1997). Since assessment of performance of an entity in cheese ripening is difficult and time-consuming, the use of model systems appears promising, provided that actual conditions prevailing in cheese can be sufficiently approximated.

\section{CONCLUSIONS}

During the $24 \mathrm{~h}$ of ripening considered, no significant differences were found between the peptide profiles of cheese-like systems made with crude aqueous extracts of C. cardunculus or with cardosin A isolated therefrom. Even though the peak areas were higher in the former case, cardosin A seems to be the main actor in primary proteolysis (with starter cultures playing a negligible role during this period). The major cleavage sites of the whole set of caseins are Phe105-Met106 in $\kappa$-casein, and Leu127-Thr128, Ser142-Trp143, Leu165-Ser166, and Leu190-Tyr191 in $\beta$-casein. The starter apparently does not contribute to initial proteolysis to a significant extent.

\section{ACKNOWLEDGMENTS}

Financial support for S. V. Silva was provided by a Ph.D. fellowship (BD/18479/98), issued by PRAXIS XXI (FCT, Portugal). This research effort received partial financial support by grants associated with projects "Enterococos: aprofundamento do conhecimento sobre o papel desempenhado por enterococos no fabrico e na maturação natural de queijos tradicionais portugueses" (POCTI/AGR/36165/99) and "MICROCHEESE: MICrostRucture of pOrtuguese CHEESEs" (POCTI/36197/ $\mathrm{BIO} / 2000)$, both issued by POCTI (FCT).

\section{REFERENCES}

Belitz, H. D., and K. P. Kaiser. 1993. Monitoring Cheddar cheese ripening by chemical indices of proteolysis. 3. Identification of several high molecular mass peptides. Z. Lebensm. Unters. Forsch. A. 197:118-122.

Benfeldt, C., and J. Sørensen. 2001. Heat treatment of cheese milk: Effect on proteolysis during cheese ripening. Int. Dairy J. 11:567-574.

Choisy, C., M. Desmazeaud, J. C. Gripon, G. Lamberet, and J. Lenoir. 2000. The biochemistry of ripening. Pages $82-151$ in Cheesemak- 
ing-From Science to Quality Assurance. A. Eck and J.-C. Gills, ed. Lavoisier, Paris, France.

Exterkate, F. A., F. M. Lagerwerf, J. Haverkamp, and S. van Schlkwijk. 1997. The selectivity of chymosin action on $\alpha_{\mathrm{s} 1}$ and $\beta$ caseins in solutions is modulated in cheese. Int. Dairy J. 7:47-54.

Fox, P. F., J. Law, P. L. M. McSweeney, and J. Wallace. 1999. Biochemistry of cheese ripening. Pages $389-438$ in Cheese: Chemistry, Physics and Microbiology. Vol. 1. P. F. Fox, ed. Aspen Publishers, Gaithersburg, MD.

Fox, P. F. 1999. Cheese: An overview. Pages 1-36 in Cheese: Chemistry, Physics and Microbiology. Vol. 1. P. F. Fox, ed. Aspen Publishers, Gaithersburg, MD.

González de Llano, D., M. C. Polo, and M. Ramos. 1995. Study of proteolysis in artisanal cheeses: HPLC of peptides. J. Dairy Sci. 78:1018-24.

Green, M. L., and A. S. Grandison. 1999. Secondary (non-enzymatic) phase of rennet coagulation and post-coagulation phenomena. Pages 101-140 in Cheese: Chemistry, Physics and Microbiology. General Aspects. Vol. 1. P. F. Fox, ed. Aspen Publishers, Gaithersburg, MD.

Hickey, M. W., A. J. Hillier, and G. R. Jago. 1983. Peptidase activities in lactobacilli. Aust. J. Dairy Technol. 38:118-123.

Hill, S. H. A., and M. J. Gasson. 1986. A qualitative screening procedure for the detection of casein hydrolysis by bacteria using sodium dodecyl sulphate polyacrylamide gel electrophoresis. J. Dairy Res. 53:625-629.

Kaiser, K. P., H. D. Belitz, and R. J. Fritsch. 1992. Monitoring Cheddar cheese ripening by chemical indices of proteolysis. 2. Peptide mapping of casein fragments by reverse-phase, high-performance liquid chromatography. Z. Lebensm. Unters. Forsch. A. 195:8-14.

Khalid, N. M., M. el Soda, and E. H. Marth. 1991. Peptide hydrolases of Lactobacillus helveticus and Lactobacillus delbrueckii spp. bulgaricus. J. Dairy Sci. 74:29-45.

Kuchroo, C. N., and P. F. Fox. 1982. Comparison of extraction procedures. Milchwissenschaft 37:331-335.

McSweeney, P. L. H., P. F. Fox, and J. Law. 1993. Contribution of cell wall-associated proteinases of Lactococcus to primary proteolysis of $\beta$-casein in Cheddar cheese. Milchwissenschaft 48:319321.

Peterson, S. D., R. T. Marshall, and H. Heyman. 1990. Peptidase profiling of lactobacilli associated with Cheddar cheese and its application to identification and selection of strains for cheeseripening studies. J. Dairy Sci. 73:1454-1464.
Picon, A., P. Gaya, M. Medina, and M. Núñez. 1995. The effect of liposome encapsulated Bacillus subtilis neutral proteinases on Manchego cheese ripening. J. Dairy Sci. 78:1238-1247.

Pires, E., C. Faro, I. Macedo, C. Esteves, J. Morgado, P. Veríssimo, D. Pereira, and D. Gomes. 1994. Flor do cardo versus quimosina no fabrico de queijos artesanais. Rev. Soc. Portuguesa Quím. 54:66-68.

Silva, S. V. 1999. Caracterização da proteólise de caseínas de ovelha e cabra catalisada por enzimas de Cynara spp. M.Sc. Thesis, Univ. Técnica de Lisboa, Lisboa, Portugal.

Silva, S. V., R. M. Barros, and F. X. Malcata. 2002. Hydrolysis of caseins by extracts of Cynara cardunculus precipitated by ammonium sulphate. J. Food Sci. 67:1746-1751.

Silva, S. V., and F. X. Malcata. 1998. Proteolysis of ovine caseins by cardosin A, an aspartic acid proteinase from Cynara cardunculus L. Lait 78:513-519.

Silva, S. V., and F. X. Malcata. 2004. Influence of the coagulant level on early proteolysis in cheese-like systems made with overheated milk. J. Food Sci. 69:579-584.

Silva, S. V., and F. X. Malcata. 2005. Studies pertaining to coagulant and proteolytic activities of plant proteases from Cynara cardunculus. Food Chem. 89:19-26.

Sousa, M. J., and F. X. Malcata. 1996. Influence of pasteurization of milk and addition of starter cultures on protein breakdown in ovine cheeses manufactured with extracts from flowers of Cynara cardunculus. Food Chem. 57:549-556

Sousa, M. J., and F. X. Malcata. 1998a. Identification of peptides from ovine milk cheese manufactured with animal rennet or extracts of Cynara cardunculus as coagulant. J. Agric. Food Chem. 46:4034-4041.

Sousa, M. J., and F. X. Malcata. 1998b. Proteolysis of ovine and caprine caseins in solution by enzymatic extracts from flowers of Cynara cardunculus. Enzyme Microb. Technol. 22:305-314.

Tavaria, F. K., and F. X. Malcata. 1998. Microbiological characterization of Serra da Estrela cheese throughout its Appélation d'Origine Protégée Region. J. Food Prot. 61:601-607.

Trujillo, A. J., C. Carretero, and B. Guamis. 1994. Los coagulantes en la industria quesera. Aliment. Equipos Tecnol.13:91-97.

Vieira de Sá, F., and M. Barbosa. 1972. Cheese-making with vegetable rennet from cardo (Cynara cardunculus). J. Dairy Res. 39:335343.

Veríssimo, P., C. Esteves, C. Faro, and E. Pires. 1995. The vegetable rennet of Cynara cardunculus L. contains two proteinases with chymosin and pepsin-like specificities. Biotechnol. Lett. $17: 621-626$. 